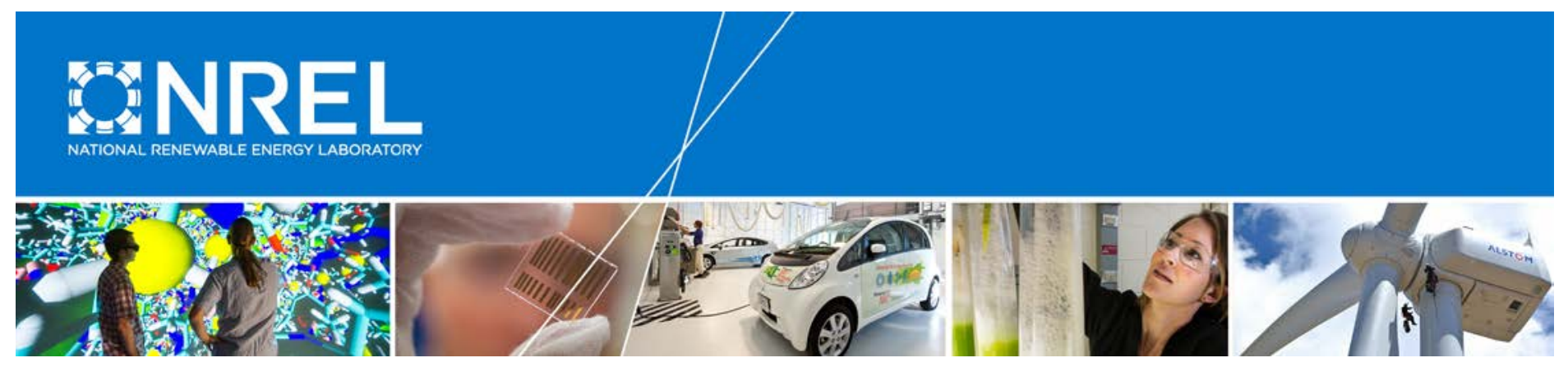

\title{
U.S. Laws and Regulations for Renewable Energy Grid Interconnections
}

Ilya Chernyakhovskiy, Tian Tian, Joyce McLaren, Mackay Miller, and Nina Geller National Renewable Energy Laboratory

NREL is a national laboratory of the U.S. Department of Energy Office of Energy Efficiency \& Renewable Energy Operated by the Alliance for Sustainable Energy, LLC

This report is available at no cost from the National Renewable Energy Laboratory (NREL) at www.nrel.gov/publications.

Technical Report

NREL/TP-6A20-66724

September 2016 


\section{U.S. Laws and Regulations for Renewable Energy Grid Interconnections}

Ilya Chernyakhovskiy, Tian Tian, Joyce McLaren, Mackay Miller, and Nina Geller National Renewable Energy Laboratory

Prepared under Task No. IGIN.1810

NREL is a national laboratory of the U.S. Department of Energy Office of Energy Efficiency \& Renewable Energy Operated by the Alliance for Sustainable Energy, LLC

This report is available at no cost from the National Renewable Energy Laboratory (NREL) at www.nrel.gov/publications.

National Renewable Energy Laboratory 15013 Denver West Parkway Golden, CO 80401

303-275-3000 • www.nrel.gov

\section{Technical Report}

NREL/TP-6A20-66724

September 2016

Contract No. DE-AC36-08G028308 


\section{NOTICE}

This report was prepared as an account of work sponsored by an agency of the United States government. Neither the United States government nor any agency thereof, nor any of their employees, makes any warranty, express or implied, or assumes any legal liability or responsibility for the accuracy, completeness, or usefulness of any information, apparatus, product, or process disclosed, or represents that its use would not infringe privately owned rights. Reference herein to any specific commercial product, process, or service by trade name, trademark, manufacturer, or otherwise does not necessarily constitute or imply its endorsement, recommendation, or favoring by the United States government or any agency thereof. The views and opinions of authors expressed herein do not necessarily state or reflect those of the United States government or any agency thereof.

This report is available at no cost from the National Renewable Energy Laboratory (NREL) at www.nrel.gov/publications.

Available electronically at SciTech Connect http:/www.osti.gov/scitech

Available for a processing fee to U.S. Department of Energy and its contractors, in paper, from:

U.S. Department of Energy

Office of Scientific and Technical Information

P.O. Box 62

Oak Ridge, TN 37831-0062

OSTI http://www.osti.gov

Phone: 865.576.8401

Fax: 865.576.5728

Email: reports@osti.gov

Available for sale to the public, in paper, from:

U.S. Department of Commerce

National Technical Information Service

5301 Shawnee Road

Alexandria, VA 22312

NTIS http://www.ntis.gov

Phone: 800.553 .6847 or 703.605 .6000

Fax: 703.605.6900

Email: orders@ntis.gov 


\section{Acknowledgments}

This report was funded under the U.S.-China Renewable Energy Partnership through the U.S. Department of Energy's Office of Energy Efficiency and Renewable Energy's International Team. The authors would like to thank the U.S.-China Renewable Energy Partnership team for the opportunity to collaborate on the scoping and development of this study. For their review and comments, the authors would like to thank David Hurlbut, Jaquelin Cochran, Jeffrey Logan, and Karin Haas from the National Renewable Energy Laboratory, and Yongqiang Zhao and Linlin Qi from the Energy Research Institute of the National Development and Reform Commission. Any errors or omissions are solely the responsibility of the authors. 


$\begin{array}{ll}\text { Abbreviations and Acronyms } \\ \text { DG } & \text { distributed generation } \\ \text { DOE } & \text { U.S. Department of Energy } \\ \text { EPAct } & \text { Energy Policy Act } \\ \text { ERCOT } & \text { Electric Reliability Council of Texas } \\ \text { EWG } & \text { exempt wholesale generator } \\ \text { FERC } & \text { Federal Energy Regulatory Commission } \\ & \text { (United States) } \\ \text { FIT } & \text { feed-in tariff } \\ \text { IPP } & \text { independent power producer } \\ \text { ISO } & \text { independent system operator } \\ \text { NERC } & \text { North American Electric Reliability Corporation } \\ \text { OASIS } & \text { open access same-time information system } \\ \text { OATT } & \text { open access transmission tariff } \\ \text { PTC } & \text { production tax credit } \\ \text { PUC } & \text { public utility commission } \\ \text { PUHCA } & \text { Public Utility Holding Company Act } \\ \text { PURPA } & \text { Public Utility Regulatory Policies Act } \\ \text { PV } & \text { photovoltaic } \\ \text { RPS } & \text { renewable portfolio standard } \\ \text { RTO } & \text { regional transmission operator }\end{array}$




\section{Glossary of Key Terms}

Ancillary Services Regulation, Spinning Reserve, Non-Spinning Reserve, Voltage Support, Black Start and other grid services that the system operator may develop to support transmission while maintaining reliable operation of the electric power grid. ${ }^{1}$

Balancing Authority The entity responsible for integrating resource plans ahead of time, maintaining load-interchange-generation balance within a Balancing Authority Area, and supporting interconnection frequency in real time. ${ }^{2}$

Bulk Electric System NERC defines Bulk Electric System as transmission elements operated at 100 kilovolts $(\mathrm{kV})$ or higher or real power and reactive power resources connected at $100 \mathrm{kV}$ or higher. $^{3}$

Cogenerator A generating unit that produces electric energy and forms of useful thermal energy used by an industrial or commercial host for industrial or commercial heating or cooling purposes. $^{2}$

Exempt wholesale generator (EWG) an independent power producer selling exclusively to wholesale customers. An EWG is exempt from certain requirements under the Public Utilities Holding Company Act of 1935. EWGs obtain their status upon determination and approval by FERC. $^{2}$

Independent power producer (IPP) A corporation, person, agency, authority, other legal entity or instrumentality that owns or operates facilities for the generation of electricity for use primarily by the public, and that is not an electric utility. ${ }^{2}$

Low voltage ride-through (LVRT) The capability of electric generators to continue to operate and stay connected to the network in periods of short-term low grid voltage.

Point of Interconnection (POC) The physical location where the power generation facility connects to the grid system.

Power purchase agreement (PPA) A financial mechanism through which a bulk electricity customer enters into a long-term electricity supply contract with an IPP. The contract defines all the terms and conditions of the transaction of electricity sales between the supplier and buyer, including dates of commencement and termination, terms of payment, schedule for delivery, penalties, and exclusions.

Primary frequency response (PFR) A resource standing by to provide autonomous, preprogrammed changes in output to rapidly arrest large changes in frequency until dispatched resources can take over (FERC 2015c).

${ }^{1}$ Adapted from California ISO (2015).

${ }^{2}$ Adapted from FERC (2013c).

${ }^{3}$ See NERC (2014) for the full NERC definition of Bulk Electric System. 
Public utility commission (PUC) A regulatory body that oversees regulation of rates and services of a public utility. It can also be referred to as a utilities commission, utility regulatory commission, or public service commission.

Qualifying facility (QF) A cogeneration or small power production facility that meets certain ownership, operating, and efficiency criteria established by the Federal Energy Regulatory Commission pursuant to the Public Utility Regulatory Policies Act. ${ }^{4}$

Variable Renewable Energy (VRE) Generator A renewable electricity generator, such as wind and or solar power plants, which provides variable and non-dispatchable power output due to the natural variability of the energy resource.

${ }^{4}$ Adapted from FERC (2013c). 


\section{Table of Contents}

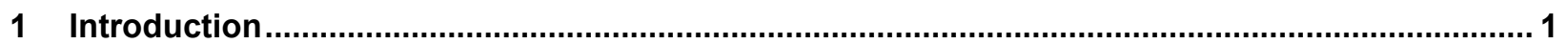

2 Regulatory Jurisdiction for Renewable Energy Grid Interconnections ........................................ 2

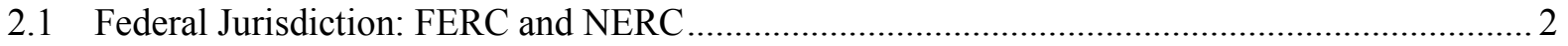

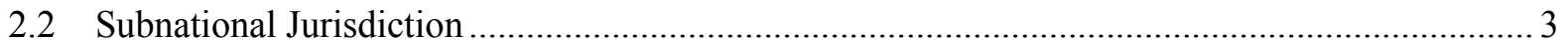

3 United States' Federal Laws and Regulations on New Energy Grid Interconnections................ 8

3.1 Early Developments of Utility Regulation in the United States.............................................. 10

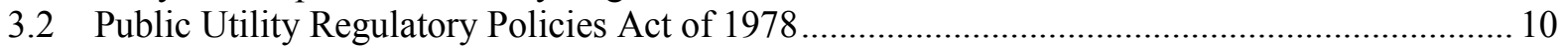

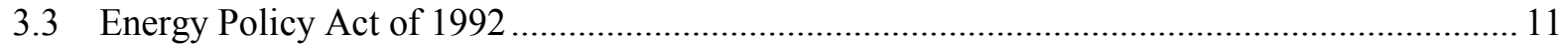

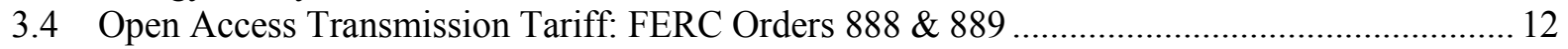

3.5 Regional Transmission Organizations: FERC Order 2000 .................................................. 12

3.6 Standardized Interconnection Procedures for Large Generators: FERC Orders 2003 \& $661 \ldots . .13$

3.7 Standardized Interconnection Procedures for Small Generators: FERC Orders 2006 \& $792 \ldots . .13$

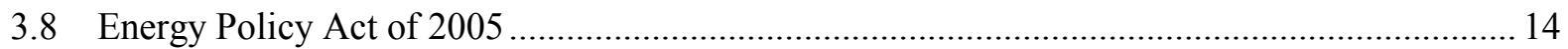

3.9 Coordinated Transmission Planning and Cost Allocation: FERC Orders 890 \& 1000.............. 15

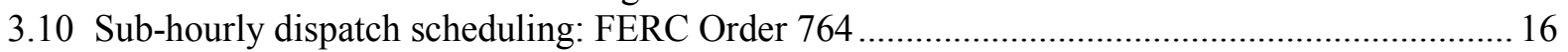

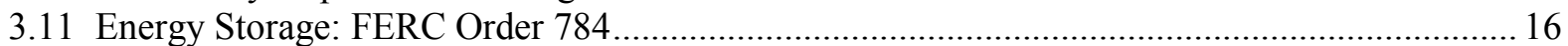

3.12 Primary Frequency Response and Reactive Power: FERC Orders 819 \& 827 ........................ 17

3.13 Summary of Federal Interconnection Policies ...................................................................... 18

4 Subnational Policies on Renewable Energy Grid Interconnections ......................................... 19

4.1 Transmission and Integration Planning: Regional and State Initiatives................................... 19

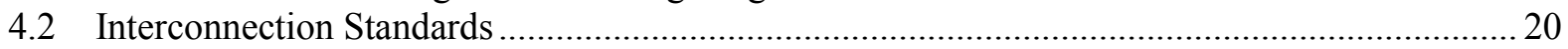

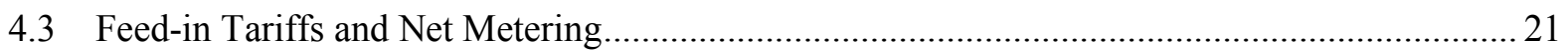

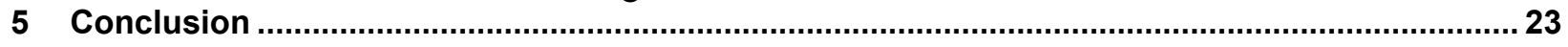

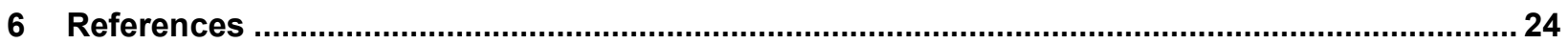

\section{Figures, Tables, and Text Boxes}

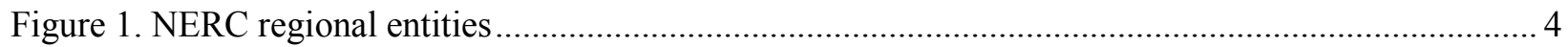

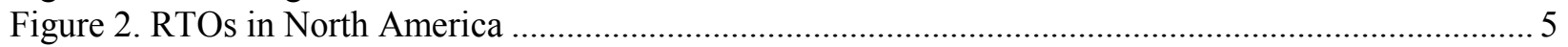

Figure 3. Jurisdictions for transmission regulation in the United States.................................................. 6

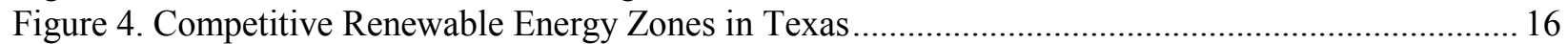

Figure 5. States with net metering policies (as of February 2016) .......................................................... 22

Table 1. FERC's and NERC's roles in national interconnection policies ............................................. 3

Table 2. Subnational Jurisdictions for Renewable Energy Interconnection Policies.................................. 7

Table 3. Summary of Key Federal Interconnection Laws and Regulations.............................................. 8

Table 4. FERC Order 792 Fast-Track Criteria for Inverter-Based Systems ........................................... 14

Table 5. Interconnection Topics Addressed by Federal Transmission Policies......................................... 18

Text Box 1. FERC Jurisdiction in the ERCOT Interconnection .......................................................... 5

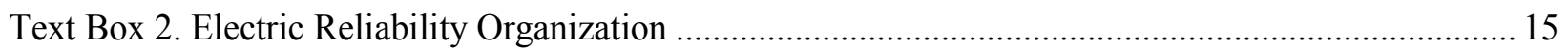

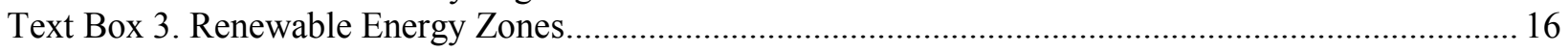

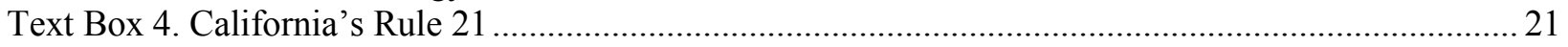




\section{Introduction}

Rapidly declining costs of wind and solar energy technologies, increasing concerns about the environmental and climate change impacts of fossil fuels, and sustained investment in renewable energy projects all point to a not-so-distant future in which renewable energy plays a pivotal role in the electric power system of the $21^{\text {st }}$ century. In light of public pressures and market factors that hasten the transition towards a low-carbon system, power system planners and regulators are preparing to integrate higher levels of variable renewable generation into the grid. Updating the regulations that govern generator interconnections and operations is crucial to ensure system reliability while creating an enabling environment for renewable energy development.

Grid interconnection policies are an important component of broader reforms and market factors influencing renewable energy integration into the grid. In the United States, laws and regulations governing the electric power sector and renewable energy interconnections have evolved significantly in recent decades through a process known as restructuring. ${ }^{5}$ Interconnection policies have gradually evolved to expand opportunities for independent generators, including renewable energy generators, to participate in different aspects of the electric power system.

This report presents a brief chronological review of energy laws and regulations concerning grid interconnection procedures in the United States, highlighting the consequences of policies for renewable energy interconnections. Where appropriate, this report places interconnection policies and their impacts on renewable energy within the broader context of power market reform.

The purpose of this report is twofold. First, it seeks to provide an accessible reference and brief overview of interconnection policies and their impacts for renewable energy in the United States. The report outlines how interconnection policies influence electricity markets and renewable energy development through regulation of transmission access and ratemaking, dispatch procedures, technology requirements, system planning, and interconnection procedures. Second, the paper attempts to clearly outline the relevant stakeholders and institutional framework under which interconnection regulations in the United States have been developed and implemented.

This report proceeds as follows: Section 2 describes the division of regulatory jurisdiction between states and federal agencies; Section 3 provides a chronological overview of federal interconnection laws and regulations and describes their consequences for renewable energy interconnections. Section 4 reviews subnational laws and regulations for renewable energy interconnections, and Section 5 concludes.

\footnotetext{
5 The term "restructuring" can refer to two different parts of the utility market: wholesale and retail electricity markets. Restructured wholesale markets comprise a range of different market-based approaches to balancing bulk power supply and demand while creating an institutional separation between transmission operations and generation. Retail restructuring refers to the introduction of consumer choice among competing suppliers of end-use electric services.
} 


\section{Regulatory Jurisdiction for Renewable Energy Grid Interconnections}

In the United States, jurisdiction over energy and electricity interconnection is divided into two distinct levels of governance: federal and state authority. At the national level, the Federal Energy Regulatory Commission (FERC) has authority over all interstate and wholesale electricity commerce. States have jurisdiction over intrastate interconnections, but have limited authority over facilities that provide services across state lines or participate in interstate wholesale electricity markets.

\subsection{Federal Jurisdiction: FERC and NERC}

As stated by the Department of Energy Organization Act of 1977, FERC has jurisdiction over interstate energy and electricity commerce. Regulatory decisions (Orders) issued by FERC are proposed, deliberated, and decided by commissioners who are appointed by the president of the United States and serve staggered five-year terms (Quinn 2015). FERC's authority to regulate interstate electricity commerce is rooted in the "Interstate Commerce Clause" from Article I, Section 8 of the U.S. Constitution, which states that the United States Congress has regulatory authority over commerce that crosses state boundaries. The Federal Power Act of 1935 granted FERC's predecessor, the Federal Power Commission, authority to "provide effective federal regulation of the expanding business of transmitting and selling electric power in interstate commerce" (Snarr 2015; 16 U.S.C. § 824). This law effectively extended federal regulatory jurisdiction to all interstate transmission infrastructure and generators engaged in wholesale electricity commerce.

The Supreme Court of the United States has ultimate authority to rule on FERC's authority to regulate interconnection requirements, transmission planning, and tariffs. The results of Supreme Court decisions identify the limitations of FERC's authority and lay the framework within which FERC can issue and enforce the Orders that are discussed in section three of this report. FERC does not have jurisdiction over local distribution of electricity, retail sales rates, siting, construction, environmental matters, or generator safety requirements, with some exceptions for hydroelectric facilities (Greenfield 2010). ${ }^{6}$

The North American Electric Reliability Corporation (NERC) ensures the reliability of the North American bulk electric system, which is divided into three independent interconnections: Eastern Interconnection, Western Interconnection, and Electricity Reliability Council of Texas (ERCOT) Interconnection. ${ }^{7}$ NERC assesses the system's reliability, develops reliability standards, and has the authority to enforce standards. FERC approves proposed changes and directs NERC to develop modifications to reliability standards in an ongoing process that is designed to respond to changing market conditions and transmission system properties. In 2007, compliance with NERC Reliability Standards became compulsory for bulk-power system owners, operators, and users. Table 1 summarizes FERC's and NERC's roles in setting and implementing national interconnection policies.

\footnotetext{
${ }^{6}$ FERC's authority over hydroelectric facilities is rooted in federal authority over waterways.

${ }^{7}$ NERC's definition, as approved by FERC in 2014, indicates that the bulk electric system includes all transmission elements operated at $100 \mathrm{kV}$ or higher and real power and reactive power resources connected at $100 \mathrm{kV}$ or higher (NERC 2014).
} 
Table 1. FERC's and NERC's roles in national interconnection policies

\begin{tabular}{|c|c|c|}
\hline \multicolumn{2}{|r|}{ FERC } & NERC \\
\hline Description & $\begin{array}{l}\text { Regulates the interstate } \\
\text { transmission and wholesale } \\
\text { sales of electricity }\end{array}$ & $\begin{array}{l}\text { Electric reliability organization } \\
\text { in the United States certified } \\
\text { by FERC }\end{array}$ \\
\hline $\begin{array}{l}\text { Role in } \\
\text { interconnection } \\
\text { policies }\end{array}$ & $\begin{array}{l}\text { - Sets service quality } \\
\text { standards, including } \\
\text { specific standards for } \\
\text { voltage, frequency, and } \\
\text { other technical } \\
\text { requirements for } \\
\text { transmission services } \\
\text { - Sets, reviews, and } \\
\text { approves interstate } \\
\text { transmission tariffs } \\
\text { Issues interconnection } \\
\text { requirements for large } \\
\text { generators (>20 MW) } \\
\text { Establishes rules for } \\
\text { transmission planning. }\end{array}$ & $\begin{array}{l}\text { Designs and issues } \\
\text { reliability standards for the } \\
\text { bulk power system } \\
\text { Exercises authority to } \\
\text { enforce reliability } \\
\text { standards via financial } \\
\text { penalties. }\end{array}$ \\
\hline
\end{tabular}

\subsection{Subnational Jurisdiction}

NERC has regional entities through which interconnection policies and reliability standards are implemented. ${ }^{8}$ NERC monitors, assesses, and enforces compliance with its standards through eight regional entities, which are made up of members from all segments of the industry including utilities, federal power agencies, cooperatives, independent power producers (IPPs), power marketers, and customers. Figure 1 illustrates the eight regional reliability entities.

The regional entities can set regional reliability requirements that are more stringent or not covered by the NERC Reliability Standard (NERC 2015). For example, the Texas Reliability Entity proposed the "Primary Frequency Response in the ERCOT Region" standard, which requires sufficient frequency response from resources to maintain ERCOT's steady-state frequency. Texas Reliability Entity and NERC jointly submitted the regional requirement and received FERC approval in 2014 (FERC 2016a).

\footnotetext{
${ }^{8}$ The eight regional reliability entities in North America are: Florida Reliability Coordinating Council (FRCC), Midwest Reliability Organization (MRO), Northeast Power Coordinating Council (NPCC), ReliabilityFirst (RF), SERC Reliability Corporation (SERC), Southwest Power Pool, Inc. (SPP RE), Texas Reliability Entity (Texas RE), and Western Electricity Coordinating Council (WECC).
} 


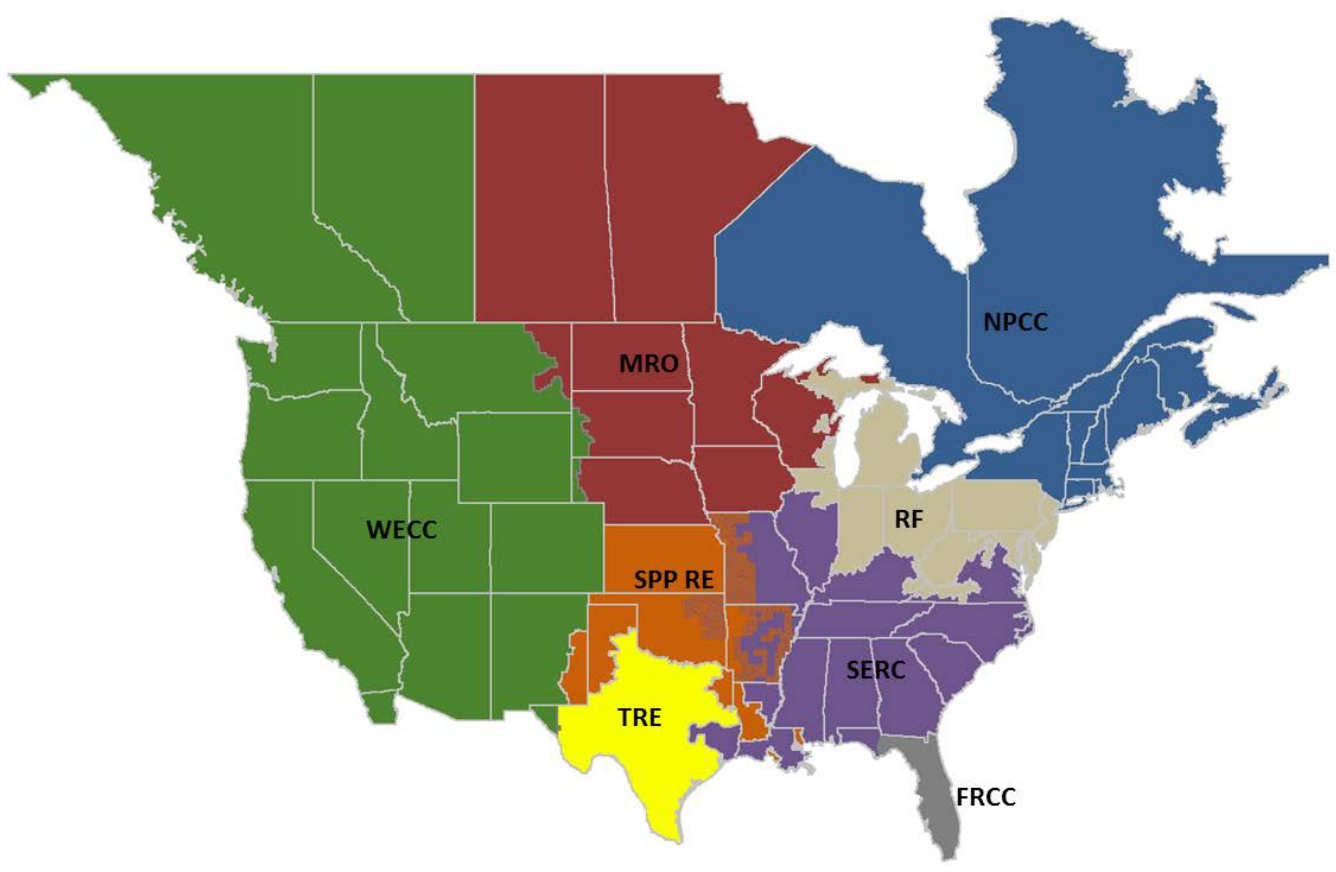

Figure 1. NERC regional entities

Source: NERC (2016)

FERC oversees the wholesale electricity market activities of balancing authorities and independent system operators (ISOs), except in ERCOT (see Text Box 1). Balancing authorities are responsible for integrating resource plans, maintaining balance of generation and load within its area, and supporting interconnection frequency in real time. In some restructured areas, balancing is the responsibility of an ISO. Regional transmission operators (RTOs) are operationally similar to ISOs, and the terms are used interchangeably. Independent balancing authorities must petition FERC to be officially designated as RTOs. ${ }^{9}$

As of March 2015, FERC has approved seven organizations as RTOs and ISOs in the United States. Figure 2 depicts the geographic layout of RTOs and ISOs in the United States, as well as two Canadian RTOs. RTOs and ISOs operate the transmission system and energy markets for about two-thirds of electricity consumers in the United States. The grid areas not under ISOs or RTOs are managed by investor-owned utilities, cooperatives, or Federal Power Marketing Administrations. All balancing authorities, including ISOs and RTOs, are required to comply with NERC reliability standards.

\footnotetext{
${ }^{9}$ The twelve minimum characteristics and functions an entity must meet to become an RTO are codified in FERC Order No. 2000.
} 


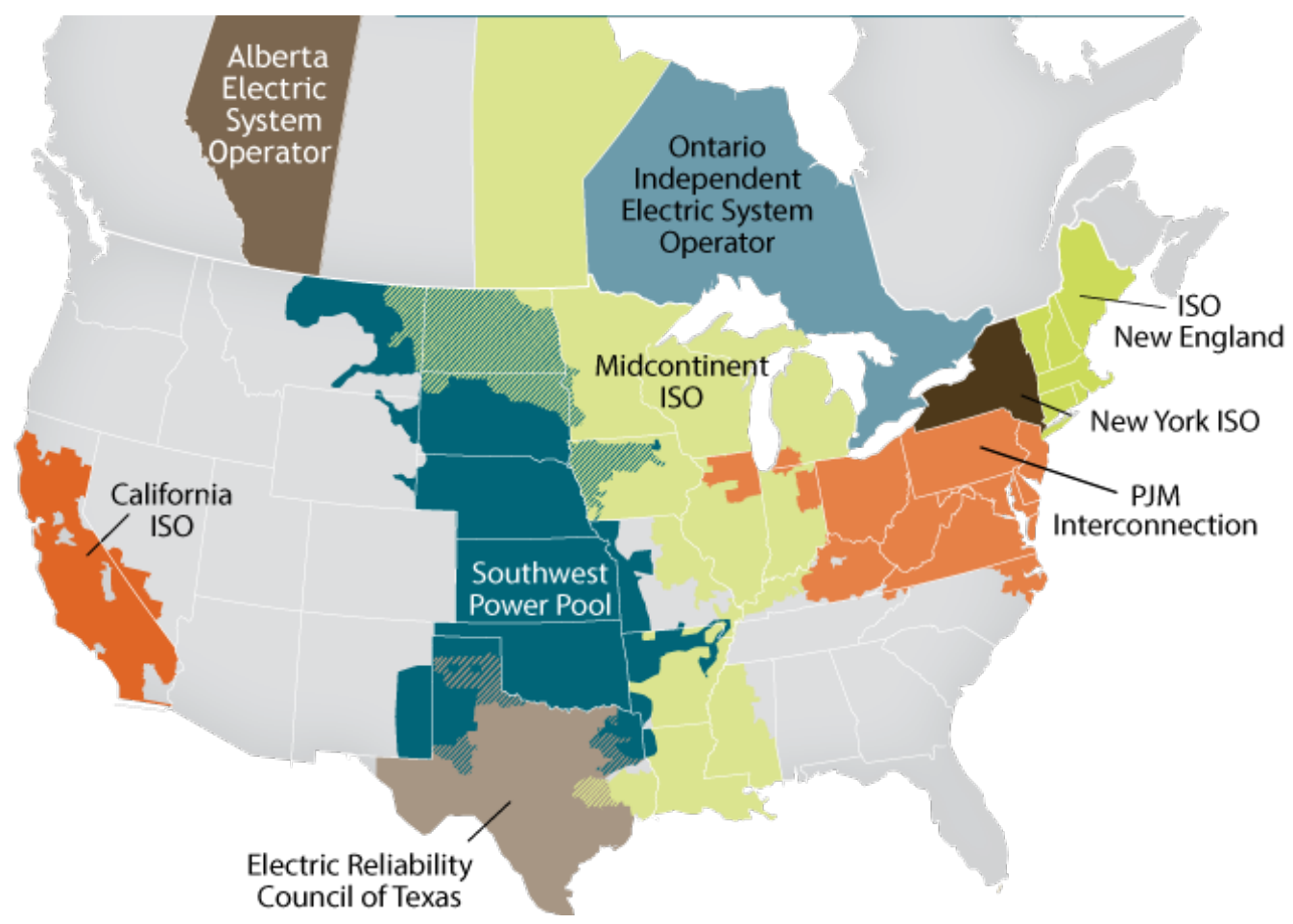

Figure 2. RTOs in North America

Source: ISORTO.org

Note: This graphic represents reliability coordination areas and not market areas.

Whereas FERC governs interstate electricity markets and services, states have jurisdiction over retail rates, generator siting, local distribution facilities, and intra-state electricity commerce, with authority to create and enforce in-state transmission regulations (Porter 1996). States also have the authority to create and implement interconnection policies for generation facilities that fall under state jurisdiction, which generally encompass distribution system-level interconnections and distributed generation (DG) systems. FERC does not have jurisdiction over interconnection procedures and power transactions for DG systems even if the facility participates in wholesale electricity markets (Fink et al. 2010).

\section{Text Box 1. FERC Jurisdiction in the ERCOT Interconnection}

ERCOT, the system operator and electricity market clearing entity for Texas, is a wholly separate statewide interconnection. The Texas interconnection is not electrically tied to power systems in any other state and hence entails no interstate commerce of any consequence for FERC oversight. FERC does not have authority to regulate transmission tariffs, wholesale market operations, prices, or generation and transmission planning in the ERCOT interconnection. The same applies to Hawaii and Alaska, which also operate wholly separate interconnections with no inter-state electricity flows. However, FERC does retain authority to regulate certain reliability standards and interconnection requirements. For example, FERC approved Texas' Regional Reliability Standard as a mandatory and enforceable requirement on generators in ERCOT with respect to the provision of primary frequency response (FERC 2016a). The Public Utility Commission of Texas regulates the wholesale electricity market in ERCOT.

Although FERC and NERC set the national interconnection and reliability technical standards, there is no unified set of interconnection requirements in the United States. The transmission or 
distribution utility, whichever hosts the point of interconnection for the electricity generator, specifies the final rules and technical specifications for interconnection to and use of the electric network. This is done through the utility's open access transmission tariff (OATT), which is reviewed and approved by FERC with input from the state public utilities regulator.

Generators under $20 \mathrm{MW}$ are generally interconnected to distribution lines and fall outside of FERC jurisdictions for transmission lines. The state government, typically though the public utilities commission, regulates interconnection and tariffs for these small generators, including establishment of timelines and requirements. Figure 3 depicts the relevant institutions and their jurisdictions for regulating interconnections in the United States. Table 2 provides descriptions of the various regulatory entities and describes their roles in establishing rules for renewable energy interconnections.

FERC

Regulates interstate transmission systems within its jurisdiction*

RTO/ISO

Regional balancing authority for participating utilities

\section{State energy regulatory agencies}

Review and provide input for transmission tariffs for utilities within the state

Utilities within ISO/RTO regions

Transmission systems are operated by $\mathrm{RTO} / \mathrm{ISO}$
Utilities outside of ISO/RTO regions

Operate transmission systems within their service areas

\section{Investor owned utilities}

Federal Power Marketing Administrations**

Cooperatives and municipal utilities**

\section{NERC}

Sets technical and reliability standards for transmission systems across the country

* FERC jurisdiction does not apply to the Texas Interconnection, Hawaii, and Alaska.

${ }^{*}$ Federal Power Marketing Administrations, cooperatives, and municipal utilities are exempt from general FERC regulation.

Some cooperatives and municipal utilities are outside of state regulatory agencies' jurisdiction.

Figure 3. Jurisdictions for transmission regulation in the United States 
Table 2. Subnational Jurisdictions for Renewable Energy Interconnection Policies

\begin{tabular}{|c|c|c|c|c|c|}
\hline Agency & $\begin{array}{l}\text { Regional } \\
\text { Reliability } \\
\text { Entities }\end{array}$ & RTO/ISO & Utilities & $\begin{array}{l}\text { State Public Utility Commission, } \\
\text { Utility Regulatory Commission, or } \\
\text { Public Service Commission }\end{array}$ & $\begin{array}{l}\text { Local and/or Municipal } \\
\text { Regulatory Authority }\end{array}$ \\
\hline Description & $\begin{array}{l}\text { Regional entities } \\
\text { of NERC made up } \\
\text { of members from } \\
\text { utilities, IPPs, and } \\
\text { transmission } \\
\text { companies }\end{array}$ & $\begin{array}{l}\text { Independent, not-for- } \\
\text { profit balancing } \\
\text { authority that operates } \\
\text { a region's grid (i.e., } \\
\text { scheduling, dispatch, } \\
\text { transmission } \\
\text { congestion } \\
\text { management, } \\
\text { purchasing, or } \\
\text { balancing services), } \\
\text { administers the region's } \\
\text { wholesale electricity } \\
\text { market, and ensures } \\
\text { reliable transmission } \\
\text { planning in the region. }\end{array}$ & $\begin{array}{l}\text { Areas without RTO/ISO: } \\
\text { an investor-owned, } \\
\text { publicly owned, or } \\
\text { cooperative balancing } \\
\text { authority that owns } \\
\text { generation, procures } \\
\text { power, and operates the } \\
\text { transmission and } \\
\text { distribution system within } \\
\text { its service area } \\
\text { Areas with RTO/ISO: a } \\
\text { utility that procures power } \\
\text { and sells power to end- } \\
\text { users but yields operations } \\
\text { of the transmission system } \\
\text { to RTO/ISO. }\end{array}$ & $\begin{array}{l}\text { State government entity that oversees } \\
\text { and regulates the services of investor- } \\
\text { owned utilities including electric power, } \\
\text { natural gas, water, and } \\
\text { telecommunications companies }\end{array}$ & $\begin{array}{l}\text { Local government entity, } \\
\text { typically under the purview } \\
\text { of a city council, that } \\
\text { oversees and regulates } \\
\text { the services of publicly } \\
\text { owned or cooperative city } \\
\text { utilities including electric } \\
\text { power, natural gas, water, } \\
\text { and telecommunications } \\
\text { companies }\end{array}$ \\
\hline $\begin{array}{l}\text { Role in } \\
\text { renewable } \\
\text { energy } \\
\text { interconne- } \\
\text { ction }\end{array}$ & $\begin{array}{l}\text { Develop, } \\
\text { implement, and } \\
\text { enforce reliability } \\
\text { standards } \\
\text { Write regional } \\
\text { standards that } \\
\text { require approval } \\
\text { by FERC and } \\
\text { NERC }\end{array}$ & $\begin{array}{l}\text { Operationalizes FERC } \\
\text { and NERC standards } \\
\text { according to } \\
\text { market/grid } \\
\text { characteristics } \\
\text { Issues interconnection } \\
\text { agreements } \\
\text { Conducts } \\
\text { interconnection } \\
\text { feasibility studies }\end{array}$ & $\begin{array}{l}\text { Operationalizes FERC and } \\
\text { NERC standards } \\
\text { according to market/grid } \\
\text { characteristics } \\
\text { Issues interconnection } \\
\text { agreements } \\
\text { Conducts interconnection } \\
\text { feasibility studies }\end{array}$ & $\begin{array}{l}\text { Sets service quality standards including } \\
\text { standards for voltage, frequency, and } \\
\text { other technical requirements for } \\
\text { distribution services } \\
\text { Sets, reviews, and approves retail rate } \\
\text { tariffs } \\
\text { Considers and approves proposed } \\
\text { power plants } \\
\text { If capital costs are to be reimbursed by } \\
\text { rate-payers, conducts prudence reviews } \\
\text { to determine whether projects are } \\
\text { completed at reasonable cost }\end{array}$ & $\begin{array}{l}\text { Considers and approves } \\
\text { proposed power plants } \\
\text { Conducts prudence } \\
\text { reviews to determine } \\
\text { whether capital projects } \\
\text { are completed at } \\
\text { reasonable cost }\end{array}$ \\
\hline
\end{tabular}




\section{United States' Federal Laws and Regulations on New Energy Grid Interconnections}

The United States has several federal laws and regulations governing renewable energy grid interconnections. Table 3 summarizes the federal laws and regulations discussed in this chapter. It is common for subsequent rules and regulations to amend and/or nullify previous provisions that are deemed ineffective and outdated. The rest of this section provides a brief history of interconnection policies and explores their impacts on renewable energy generators in the United States.

Table 3. Summary of Key Federal Interconnection Laws and Regulations

\begin{tabular}{|c|c|c|c|}
\hline $\begin{array}{l}\text { Laws and } \\
\text { Regulations }\end{array}$ & Year & Key Points & $\begin{array}{l}\text { Key Implications for } \\
\text { Renewable Energy } \\
\text { Interconnections }\end{array}$ \\
\hline $\begin{array}{l}\text { Federal Power Act } \\
\text { (FPA) }\end{array}$ & $\begin{array}{l}1935 \\
\text { (subsequently } \\
\text { amended } \\
\text { numerous } \\
\text { times) }\end{array}$ & $\begin{array}{l}\text { Federal Power Commission } \\
\text { established to oversee } \\
\text { wholesale and interstate } \\
\text { electricity transactions } \\
\text { Continues to be the primary } \\
\text { source of federal authority } \\
\text { over electric utilities. }\end{array}$ & $\begin{array}{l}\text { Beginning of federal oversight } \\
\text { of the power sector }\end{array}$ \\
\hline $\begin{array}{l}\text { Public Utility } \\
\text { Regulatory Policy Act } \\
\text { (PURPA) }\end{array}$ & $\begin{array}{l}1978 \\
\text { (amended in } \\
2005)\end{array}$ & $\begin{array}{l}\text { Utilities required to buy } \\
\text { electricity from qualifying } \\
\text { facilities, injecting } \\
\text { competition into wholesale } \\
\text { power markets }\end{array}$ & $\begin{array}{l}\text { Foundational policy that paved } \\
\text { the way for small non-utility } \\
\text { generators to enter the market, } \\
\text { including renewable energy } \\
\text { developers }\end{array}$ \\
\hline $\begin{array}{l}\text { Energy Policy Act of } \\
1992\end{array}$ & 1992 & $\begin{array}{l}\text { Created exempt wholesale } \\
\text { generators to participate in } \\
\text { wholesale power markets } \\
\text { free from Security and } \\
\text { Exchange Commission } \\
\text { (SEC) oversight }\end{array}$ & $\begin{array}{l}\text { Exemption from SEC scrutiny } \\
\text { encouraged investment in IPPs } \\
\text { by private investment } \\
\text { companies }\end{array}$ \\
\hline $\begin{array}{l}\text { FERC Orders } 888 \text { \& } \\
\mathbf{8 8 9} \\
\text { Open Access } \\
\text { Transmission and } \\
\text { OASIS }\end{array}$ & 1996 & $\begin{array}{l}\text { Codified the OATT } \\
\text { Established the Open } \\
\text { Access Same-Time } \\
\text { Information System } \\
\text { (OASIS) }\end{array}$ & $\begin{array}{l}\text { Reduced transmission barriers } \\
\text { for renewable energy } \\
\text { generators, enabling renewable } \\
\text { energy plants to choose among } \\
\text { wholesale buyers } \\
\text { Gave renewable energy } \\
\text { developers open access to } \\
\text { market-critical data including } \\
\text { transmission capacity and } \\
\text { prices }\end{array}$ \\
\hline $\begin{array}{l}\text { FERC Order } 2000 \\
\text { Regional Transmission } \\
\text { Organizations }\end{array}$ & 1999 & $\begin{array}{l}\text { Transmission utilities } \\
\text { strongly encouraged to join } \\
\text { an RTO/ISO } \\
\text { Describes characteristics } \\
\text { and functions required for } \\
\text { entities to become an RTO }\end{array}$ & $\begin{array}{l}\text { Larger balancing areas and } \\
\text { real-time balancing better } \\
\text { enable higher penetrations of } \\
\text { variable renewable energy } \\
\text { generation }\end{array}$ \\
\hline
\end{tabular}




\begin{tabular}{|c|c|c|c|}
\hline $\begin{array}{l}\text { Laws and } \\
\text { Regulations }\end{array}$ & Year & Key Points & $\begin{array}{l}\text { Key Implications for } \\
\text { Renewable Energy } \\
\text { Interconnections }\end{array}$ \\
\hline $\begin{array}{l}\text { FERC Orders } 2003 \& \\
661 \\
\text { Interconnection } \\
\text { Procedures for Large } \\
\text { Generators }\end{array}$ & 2003,2005 & $\begin{array}{l}\text { Standard interconnection } \\
\text { procedures for large } \\
\text { generators (>20 MW) } \\
\text { Codified interconnection } \\
\text { standards for wind } \\
\text { generators }\end{array}$ & $\begin{array}{l}\text { Reduced the timeframe and } \\
\text { cost of interconnection for large } \\
\text { renewable energy generators } \\
\text { Required low voltage ride- } \\
\text { through, reactive power, and } \\
\text { SCADA capability in wind plants }\end{array}$ \\
\hline $\begin{array}{l}\text { FERC Order } 2006 \text { \& } \\
792 \\
\text { Interconnection } \\
\text { Procedures for Small } \\
\text { Generators }\end{array}$ & 2005,2013 & $\begin{array}{l}\text { Standard interconnection } \\
\text { procedures for small } \\
\text { generators (<20 MW) }\end{array}$ & $\begin{array}{l}\text { Reduced the timeframe and } \\
\text { cost of interconnection for small } \\
\text { renewable energy generators } \\
\text { Established a fast-track process } \\
\text { for small renewable energy } \\
\text { systems } \\
\text { Included energy storage } \\
\text { devices in the Small Generator } \\
\text { Interconnection Procedure and } \\
\text { Small Generator } \\
\text { Interconnection Agreement }\end{array}$ \\
\hline $\begin{array}{l}\text { Energy Policy Act of } \\
2005\end{array}$ & 2005 & $\begin{array}{l}\text { Terminated long-term } \\
\text { PURPA contracts, } \\
\text { abandoned the avoided } \\
\text { cost rate principle, and } \\
\text { provided tax incentives for } \\
\text { transmission system } \\
\text { improvements }\end{array}$ & $\begin{array}{l}\text { Increased competition in } \\
\text { wholesale power markets by } \\
\text { forcing out uneconomical } \\
\text { projects }\end{array}$ \\
\hline $\begin{array}{l}\text { FERC Orders } 890 \text { \& } \\
1000 \\
\text { Transmission Planning } \\
\text { and Cost Allocation }\end{array}$ & 2007,2011 & $\begin{array}{l}\text { Transmission providers } \\
\text { required to conduct } \\
\text { transmission planning at } \\
\text { the regional and local level } \\
\text { Added flexibility to methods } \\
\text { of cost allocation of } \\
\text { transmission upgrades }\end{array}$ & $\begin{array}{l}\text { Improved transmission planning } \\
\text { reduces grid congestion and } \\
\text { promotes access to new } \\
\text { sources of energy, including } \\
\text { solar and wind resources } \\
\text { Broad allocation of transmission } \\
\text { upgrade costs reduces financial } \\
\text { burden for renewable energy } \\
\text { plants }\end{array}$ \\
\hline $\begin{array}{l}\text { FERC Order } 764 \\
\text { Integration of Variable } \\
\text { Energy Resources }\end{array}$ & 2012 & $\begin{array}{l}\text { Required transmission } \\
\text { owners to provide 15- } \\
\text { minute scheduling }\end{array}$ & $\begin{array}{l}\text { Enabled renewable energy } \\
\text { generators to better respond to } \\
\text { resource variability in their } \\
\text { power delivery schedules }\end{array}$ \\
\hline $\begin{array}{l}\text { FERC Order } 784 \\
\text { Ancillary Services and } \\
\text { Electric Energy } \\
\text { Storage }\end{array}$ & 2013 & $\begin{array}{l}\text { Amended ancillary services } \\
\text { markets to include "pay-for- } \\
\text { performance" pricing based } \\
\text { on speed and precision }\end{array}$ & $\begin{array}{l}\text { Increased opportunities and } \\
\text { incentives for energy storage to } \\
\text { participate in ancillary services } \\
\text { markets }\end{array}$ \\
\hline
\end{tabular}




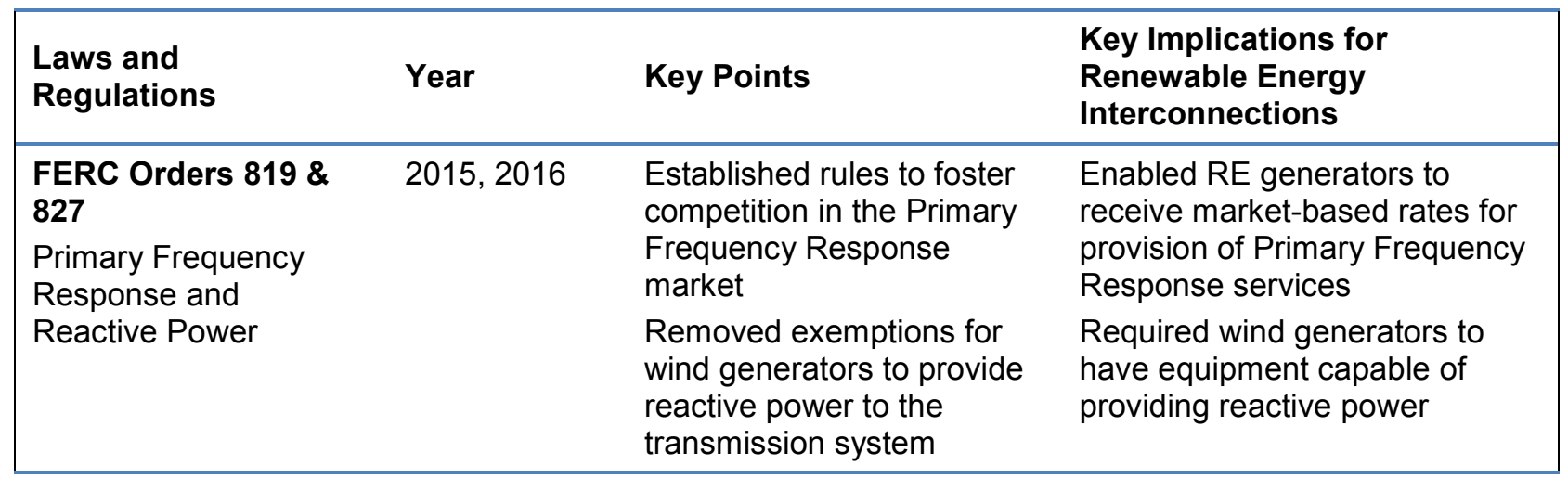

\subsection{Early Developments of Utility Regulation in the United States}

In the late 19th and early 20th centuries, electric power distribution systems in the United States consisted of independent, localized generators that supplied individual end-use consumers with direct current interconnections. Early electric power companies were regulated by local authorities in the cities they served. Electricity distribution over large distances at affordable rates began with the development and mass introduction of alternating current and steam turbines. These technology developments enabled electric power companies to expand their services beyond city and state boundaries. The electric power industry became dominated by large interstate companies that maintained vertical monopoly control over all aspects of generation, transmission, and distribution. While highly profitable for utility companies and their investors, this state of the market left consumers vulnerable to monopoly pricing and provided little incentive for utilities to expand distribution services to customers in rural areas (Trachsel 1947, Casazza and Delea 2004).

In 1935, Congress passed the Public Utility Holding Company Act (PUHCA), taking the first step toward establishing federal oversight of electric utilities. The PUHCA required interstate utility holding companies to register with the SEC and submit financial accounts of their transactions, operations, and holdings. Also in 1935, Congress passed the Federal Power Act, which gave the Federal Power Commission regulatory oversight of wholesale interstate transactions of electric power. The Federal Power Commission mandate was to ensure that electricity rates were "reasonable, nondiscriminatory and just to the consumer" (16 U.S.C. chapter 12).

Following the Federal Power Act of 1935, interconnection policies and utility regulations remained largely unchanged until the 1970s. The intervening decades saw electricity prices steadily decline while the industry enjoyed steady growth in electricity demand and improvements in the efficiency of supply (Casazza and Delea 2004).

\subsection{Public Utility Regulatory Policies Act of 1978}

Amidst the backdrop of rising inflation and the oil embargo of 1973, President James Carter's administration enacted the Public Utility Regulatory Policies Act of 1978 (PURPA) as part of the National Energy Act (Pub. L. 95-617). In addition to establishing guidelines for more efficient rate structures, PURPA required utilities to purchase wholesale electricity from IPPs that could supply electricity at lower cost than the utility's generation cost. This step helped diversify electricity supply and opened the door to competition in electric power markets by removing the 
barriers to entry for small generators. PURPA created two classes of qualifying facilities that could vie for utility interconnection contracts: qualifying cogeneration facilities, which produce both electricity and useful heat from fossil fuels, and qualifying small power production facilities, which produce electricity from renewable resources or biomass and waste (Hirsh 1999). Utilities were required to purchase electricity generated from qualifying facilities at a rate equal to avoided cost, which is the marginal cost of electricity production for the utility, as determined on a case-by-case basis in public hearings administered by local public utility commissions (PUCs) (IEPA 2015).

The avoided-cost rate structure created a favorable environment for small non-utility generators. Non-utility generating capacity steadily increased in the 20 years following the passage of PURPA, with the majority of new capacity coming from cogeneration facilities (Dismukes and Kleit 1999). In some states, favorable avoided-cost rates, along with generous state and federal tax incentives, spurred investor interest in renewable energy. However, deployment was highly subject to states' regulatory and investment climate. In 1979, California's PUC imposed fines on state utilities for failing to consider alternative energy targets in their future generation mix. By the 1980's, California had a combination of the most favorable power purchase rates in the United States, generous state tax credits, a positive investment climate, and an abundance of lowcost land with energetic wind resources. In 1991, California reached $80 \%$ of the world's installed wind power capacity (Gipe 1991).

\subsection{Energy Policy Act of 1992}

In the wake of the Persian Gulf conflict, in 1992 the U.S. Congress passed the Energy Policy Act of 1992 (EPAct 1992). EPAct 1992 was designed to decrease the dependence of the United States on foreign oil and bolster energy security through energy efficiency improvements and incentives for clean energy development. EPAct 1992 was the first piece of legislation since PURPA to continue the deregulation of electric power markets. Designed as an amendment to PURPA, the power sector provisions of EPAct 1992 took additional steps to inject competition into wholesale electricity markets. The amendment established a new class of electricity generators, exempt wholesale generators (EWGs), which would be exempt from regulation under the PUHCA (Burns and Eifert 1993). Exemption from PUHCA meant that EWGs could engage in interstate wholesale electricity transactions without SEC scrutiny of holding company finances and transactions. This step enabled utilities and non-utilities to simplify corporate structures and encouraged investments in IPPs (Abel 1998).

Under EPAct 1992, FERC was tasked to oversee wholesale transactions from EWGs, with the authority to give case-by-case approval for long-term power purchase agreements (PPAs) between EWGs and wholesale power purchasers. EPAct 1992 also included an amendment to the Federal Power Act that granted transmission services to EWGs or any other wholesale power producer. Any power producer could now appeal to FERC for access to a utility's transmission infrastructure in order to fulfill contracts with geographically disparate wholesale power purchasers. The amendment also instigated prolonged legal battles between transmission utilities, regulators and power producers to resolve conflicts over the rates that utilities could charge for transmission services (Watkiss and Smith 1993). The ratemaking conflicts would be resolved with the issuance of FERC Order 888 in 1996. 


\subsection{Open Access Transmission Tariff: FERC Orders 888 \& 889}

In April 1996, FERC Order 888 picked up where EPAct 1992 left off concerning open access transmission policies. First, FERC Order 888 officially codified open access transmission. Utilities were required to provide transmission customers with "equivalent service and terms" for services that a utility would otherwise provide for itself (Porter 1996). The "equivalent service and terms" provision ended years of debate regarding the rates that utilities could charge for transmission services. Utilities were required to publicly file OATTs with conditions for nondiscriminatory services (FERC 2015a). Issued in the same year, FERC Order 889 established the concept of an open access same-time information system (OASIS), requiring utilities to publish transmission capacity, prices, and other market-critical data to be readily available to all market participants via the Internet ("FERC Order 888" 1996). At the same time, the order permitted transmission providers to seek recovery of stranded costs from wholesale customers who chose to switch to a third-party wholesale electricity provider (Porter 1996).

The open access provisions of Order 888 significantly reduced the barriers to entry for renewable energy power producers. Remotely located renewable energy generators like wind power plants could now use transmission networks to transport electricity to the most favorable markets, rather than sell to the nearest utility (Porter 1996). On the other hand, OATTs meant stiffer competition with more buyers and sellers putting downward pressure on electricity rates, pricing renewable energy generation out of many markets ("FERC Order 888" 1996). Additionally, Order 888 allowed transmission providers to charge a penalty to generators that deviated by $1.5 \%$ from their scheduled electricity delivery. Given the variable nature of renewable energy resources, particularly wind energy, the $1.5 \%$ variability threshold made it nearly impossible for wind generators to avoid penalty charges. Because the penalty provisions often exceeded the value of commercial wind energy, wind project developers typically had to sell variable output to an entity that could blend it with thermal generation and resell to the wholesale market (Parsons and Porter 2002).

\subsection{Regional Transmission Organizations: FERC Order 2000}

Issued in 1999, FERC Order 2000 strongly encouraged all electric utilities and transmission owners to participate in (or submit their plans to join) an RTO. A key effect of RTOs is to expand the effective geographic footprint of system operations by combining multiple balancing authorities. Larger balancing areas help to smooth out differences between load and generation over larger geographic areas. This is particularly relevant for variable renewable energy generators because larger balancing areas can provide access to greater amounts of flexible generation to support system balance. More access to flexible generation improves project economics for individual renewable energy developers and enhances overall system costeffectiveness (Cochran et al. 2012).

To further encourage renewable energy integration and improve the cost-effectiveness of variable generation, Order 2000 also mandated RTOs to implement real-time balancing markets (Merrill 2000). Real-time (minute-to-minute) balancing improves system reliability by maintaining generation-load balance at all times. The implementation of real-time balancing markets allows transmission customers to balance their energy schedules, opening the door for higher penetrations of variable renewable energy generators in wholesale power markets (Hirst 2001). 


\subsection{Standardized Interconnection Procedures for Large Generators: FERC Orders 2003 \& 661}

In July 2003, FERC Order 2003 established standardized interconnection procedures for large generators. Order 2003 issued the Large Generator Interconnection Procedure and the Large Generator Interconnection Agreement, requiring all generators under FERC jurisdiction with generating capacity more than $20 \mathrm{MW}$ to follow standard procedures to interconnect with the electricity grid. The Large Generator Interconnection Procedure consists of studies conducted by the transmission provider, which FERC uses to assess the interconnection request (Fink et al. 2010). The Large Generator Interconnection Agreement includes standardized interconnection requirements covering frequency, voltage, power factor, and reactive power standards. However, wind generators were exempt from requirements to provide reactive power primarily because it required high-cost technology that would have negatively impacted wind development at the time (FERC 2015b).

The standard procedures were primarily designed to reduce the timeframe and cost of interconnection while preserving system reliability. . As a consequence of FERC Order 2003 and its subsequent revisions, generator interconnection applications tripled from 2004 to 2007 (Porter et al. 2009).

The influx of generation interconnection requests resulted in congested interconnection queues. This backlog, in turn, increased the processing time of interconnection studies, causing project delays and frustration among renewable energy developers. The result contradicted the original intent of Order 2003. From late 2007 through 2008, FERC responded by requiring RTOs and ISOs to file status reports and propose reforms to reduce the timetable for interconnection processing and minimize the backlog of interconnection queues (Porter et al. 2009).

FERC Order 2003 made no distinction between conventional and variable renewable energy generators. A surge in penetration of variable generation from wind prompted a revision of interconnection procedures to include standards and guidelines specific to wind generation. In June 2005, FERC issued Order No. 661 requiring public utilities to add standard procedures and technical requirements for the interconnection of large wind generation units (FERC 2005). The requirements address low-voltage ride-through (LVRT) capability and supervisory control and data acquisition (SCADA) capability. Under Order 661 (also 661-A), wind plants are required to provide LVRT capability (staying connected to the grid for voltage drops of $15 \%$ of normal voltage levels), and implement SCADA information and control capability (capability to receive and react to instructions from the system operator) (Porter et al. 2009).

\subsection{Standardized Interconnection Procedures for Small Generators: FERC Orders 2006 \& 792}

Issued in 2005, FERC Order 2006 addressed interconnection standards for small generators. Order 2006 established the Small Generator Interconnection Procedure and the Small Generator Interconnection Agreement for generators with capacity up to $20 \mathrm{MW}$ (Fink et al. 2010). Since many small generators can operate without interconnection to FERC-jurisdiction transmission lines, several states used Order 2006 as a model to design and issue their own standards for small generator interconnections. Some states, including California, Hawaii, and New Jersey, impose 
no size limit for generators wishing to connect to non-FERC-jurisdiction transmission lines (Fink et al. 2010).

FERC Order 2006 also included a fast-track process for generating facilities with capacity less than $2 \mathrm{MW}$. In response to the rapid increase in small-scale, distributed solar PV deployment, FERC issued Order 792 in November 2013, which allowed inverter-based interconnections up to $5 \mathrm{MW}$ to qualify for the fast-track process if the generating system's capacity is less than or equal to the minimum load of the system host facility. Eligibility to apply for the fast-track interconnection process is based on the generator type and size, and the line voltage and type at the point of interconnection. The fast-track criteria are summarized in Table 4 (FERC 2013a).

Table 4. FERC Order 792 Fast-Track Criteria for Inverter-Based Systems

\begin{tabular}{|c|c|c|}
\hline Line Voltage & $\begin{array}{l}\text { Fast-Track Eligibility } \\
\text { Regardless of Location }\end{array}$ & $\begin{array}{l}\text { Fast-Track Eligibility on a } \\
\text { Mainline }{ }^{\mathrm{a}} \text { and } \leq 2.5 \\
\text { Electrical Circuit } \text { Miles }^{\mathrm{b}} \\
\text { from Substation }\end{array}$ \\
\hline$<5 \mathrm{kV}$ & $\leq 500 \mathrm{~kW}$ & $\leq 500 \mathrm{~kW}$ \\
\hline$\geq 5 \mathrm{kV}$ and $<15 \mathrm{kV}$ & $\leq 2 \mathrm{MW}$ & $\leq 3 \mathrm{MW}$ \\
\hline$\geq 15 \mathrm{kV}$ and $<30 \mathrm{kV}$ & $\leq 3 \mathrm{MW}$ & $\leq 4 \mathrm{MW}$ \\
\hline$\geq 30 \mathrm{kV}$ and $\leq 69 \mathrm{kV}$ & $\leq 4 \mathrm{MW}$ & $\leq 5 \mathrm{MW}$ \\
\hline
\end{tabular}

a For the purposes of this table, a mainline is the three-phase backbone of a circuit. It typically constitutes lines that have wire sizes of 4/0 American wire gauge, 336.4 kcmil, $397.5 \mathrm{kcmil}, 477 \mathrm{kcmil}$, and $795 \mathrm{kcmil}$.

b An interconnection customer can determine this distance in advance by requesting a pre-application report.

Source: FERC order 792

In addition to changing the requirements for fast-track interconnections for solar PV systems, Order 792 included storage systems in the definition of small generator facilities. Therefore, storage systems using inverter-based interconnections also qualify for fast-track application.

\subsection{Energy Policy Act of $\mathbf{2 0 0 5}$}

The Energy Policy Act of 2005, also known as EPAct 2005, focused on promoting energy efficiency improvements and energy self-sufficiency in the United States. In addition to grants for technology R\&D and energy efficiency improvements, the bill introduced substantial modifications to interconnection legislation. In particular, EPAct 2005 amended the PURPA provision that required utilities to purchase power from any qualifying facility without discrimination, a requirement which had forced utilities into high-cost, long-term contracts (Malmedal et al. 2007). EPAct 2005 established that utilities were not obliged to purchase electricity from a qualifying facility if that generator has access to alternative buyers in a competitive wholesale electricity market. PURPA's "avoided costs" rate principle was also abandoned.

EPAct 2005 went further than any previous legislation in granting FERC additional authority and responsibility to oversee the reliability of the electricity grid, implement penalties to prevent 
market manipulation, provide rate incentives to promote investment, and to oversee utility company mergers and acquisitions. The bill also established a coordinated review and permitting process for federally approved transmission projects, requiring the U.S. Department of Energy (DOE) to conduct congestion studies every three years and designate National Interest Electric Transmission Corridors (FERC 2006).

\section{Text Box 2. Electric Reliability Organization}

In response to a system reliability provision of EPAct 2005, FERC designated NERC as the nation's Electric Reliability Organization (ERO). NERC was tasked with establishing nationwide maintenance and testing standards for transmission, generation, equipment for under-frequency load shedding and undervoltage load shedding, and special protection systems. Known as the "Version 0 Standards," the NERCproposed standards were accepted and made mandatory by FERC Order 693 in 2007 (Udren and Rogers 2010).

\subsection{Coordinated Transmission Planning and Cost Allocation: FERC Orders $890 \& 1000$}

Order 890, issued in 2007, mandated transmission utilities to participate in "coordinated, open and transparent transmission planning" on a local and regional level, such that the planning needs of transmission providers and customers would be met on a "comparable and nondiscriminatory" basis (FERC 2014). Transmission providers were required to adhere to the following nine principles in the planning process: coordination, openness, transparency, information exchange, comparability, dispute resolution, regional participation, economic planning, and cost allocation. This reform was in part a response to a decline in investment relative to growth, which had led to increasing congestion due to growing levels of variable renewable energy integration (Greenfield 2010). Coordinated transmission planning helps to reduce grid strain from variable renewable energy integration and ultimately improves renewable energy project economics. Transmission access is crucial for renewable energy developers to secure financing, and a stronger grid can improve system flexibility leading to reduced renewable energy curtailment (Cochran et al. 2012).

In July 2011, FERC issued Order 1000 to continue the promotion of interregional transmission planning that began under Order 890 (FERC 2014). FERC Order 1000 revised Order 890 by requiring public utility transmission providers to produce plans for regional-wide transmission upgrades. Order 1000 also addressed longstanding questions of cost allocation for transmission upgrades and grid expansion. It amended the OATT to give regions flexibility to develop unique cost allocation methods that would balance the interests of transmission providers, customers, and the broader network (Davis 2013). This reform was important for renewable energy generators, particularly for remotely sited projects. While transmission utilities argued that the costs of transmission upgrades should be borne primarily by the transmission customer, renewable energy generators fought for a broader allocation of costs, citing society-wide benefits of renewable energy integration (Bloom 2010). 


\section{Text Box 3. Renewable Energy Zones}

A Renewable Energy Zone (REZ) is one example of the kind of transmission planning that FERC sought to induce with Orders 890 and 1000 . A REZ process is a proactive transmission planning framework that enables the development of a region's best $R E$ resources. This is a regulatory exercise that identifies the best locations for RE development and collaborates with industry stakeholders to facilitate transmission upgrades that may be needed to bring renewable energy to markets (Hurlbut et al., 2016).

In 2005, the PUC of Texas initiated the Competitive Renewable Energy Zones (CREZ) project. The project designated wind-rich areas in which new transmission would be built in advance of obtaining an interconnection agreement with developers (Hurlbut 2010). Ultimately, CREZ high-voltage transmission projects were designed to serve around $18.5 \mathrm{GW}$ of capacity. Increased transmission capacity in windrich areas and reduced transmission congestion opened the Texas market to additional wind power development. Figure 4 depicts the CREZ transmission lines in red. In 2014, the primary system operator in Texas generated more than $10 \%$ of its electricity from wind, up from $6 \%$ in 2006 (EIA 2015).

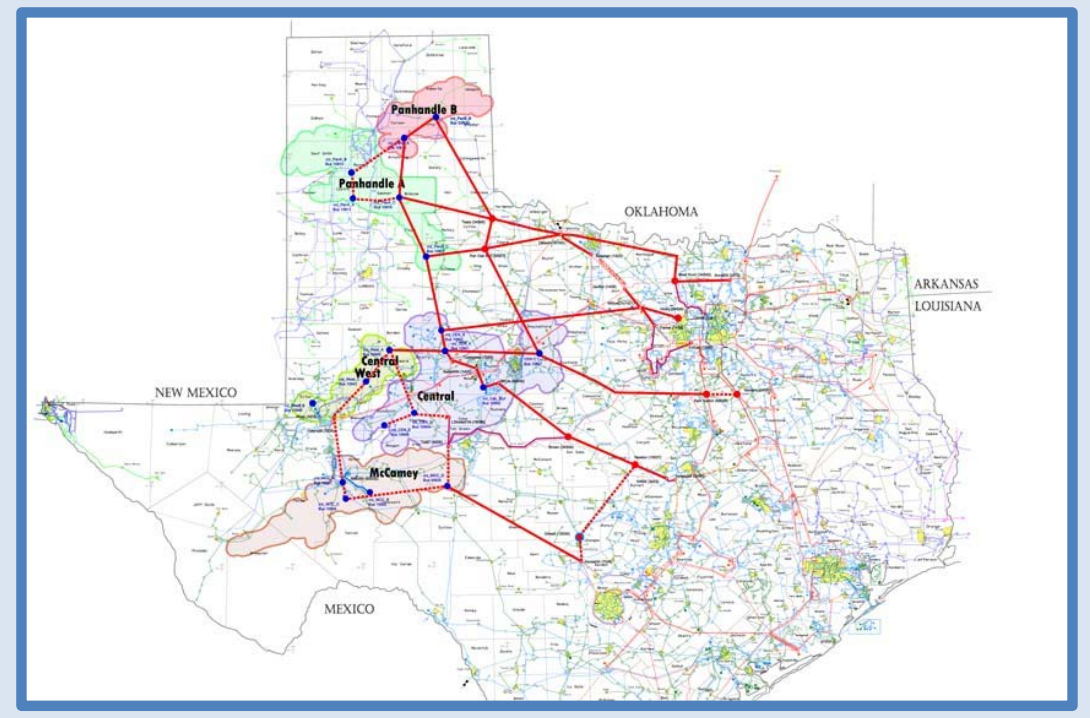

Figure 4. Competitive Renewable Energy Zones in Texas

Source: Woodfin (2008)

\subsection{Sub-hourly dispatch scheduling: FERC Order 764}

FERC Order 764 addressed concerns about integrating variable renewable energy with transmission dispatch systems. Issued in 2012, Order 764 amended the OATT to require transmission owners to offer 15-minute transmission scheduling, advancing system operation practices from the standard one-hour scheduling model (Miller and Cox 2014). Sub-hourly scheduling enables renewable energy generators to respond to changing resource conditions, i.e., sudden wind gusts or cloud coverage, allowing renewable energy transmission customers to better manage generation imbalance (GI) and energy imbalance (EI) charges (BPA 2014). Order 764 also reformed the Large Generator Interconnection Agreement to give transmission providers access to sub-hourly forecast data from renewable energy generators for the purpose of improving power production forecasts (Miller and Cox 2014).

\subsection{Energy Storage: FERC Order 784}

Energy storage can greatly enhance the ability of system operators to integrate large amounts of renewable energy generation. There are various storage technologies including fly wheels, 
compressed air storage, batteries, and pumped-hydro storage. In general, storage shifts the timing of supply to better align generation with market prices and electricity demand. In 2013, FERC Order 784 amended the pricing mechanism in ancillary service markets, requiring utilities to consider speed and precision when purchasing ancillary services (FERC 2013b). This expanded the "pay-for-performance" requirement that was originally established under FERC Order 755 in 2011. Since energy storage can provide ancillary services much faster and with more precision than gas- or coal-fired plants, Order 784 gives energy storage a price premium in ancillary services markets (Anderson 2014). Also in 2013, as discussed above, Order 792 amended the Small Generator Interconnection Agreement and Small Generator Interconnection Procedure to explicitly include energy storage.

\subsection{Primary Frequency Response and Reactive Power: FERC Orders $819 \& 827$}

One of the primary objectives of electricity system operators is to maintain electrical frequency very close to a specific level at all times. Large deviations in frequency can lead to equipment damage, involuntary load shedding, and instability in supply, all of which contribute to excessive costs. To prevent large changes in electrical frequency, conventional generators use automatic control systems in their turbine governors to provide primary frequency response (PFR) service, occurring in a timeframe from 1 s to 10 s of seconds. FERC defines PFR services "as a resource standing by to provide autonomous, pre-programmed changes in output" to prevent large changes in system frequency "until dispatched resources can take over" (FERC 2015c). Issued in November of 2015, Order 819 revised regulations related to the sale of primary frequency response service, permitting the sale of PFR services based on market-based rates. The new rules were designed to foster competition in the sale of PFR service and expand the ancillary services market.

The rules for market-based sales of PFR services apply to conventional as well as renewable energy generators. ${ }^{10}$ Modern wind generators with appropriate equipment are capable of providing PFR service with power inverter electronics that simulate inertial response, also known as "synthetic system inertia." While frequency response controls on photovoltaic, concentrated solar, and energy storage systems are not traditionally used, commercially available equipment can enable solar and energy storage plants to provide equally effective frequency response services (Zhang et. al 2013; Milligan et al. 2015). Wind, solar, and storage systems' ability to provide and sell frequency response services will become critical for maintaining system reliability as power systems incorporate higher penetrations of nonsynchronous generation. For example, Eirgrid, the system operator for the combined Ireland and Northern Ireland power system, currently applies a 50\% operating limit on the instantaneous penetration of nonsynchronous generation due to frequency stability concerns (Milligan et al. 2015).

In June of 2016, Order 827 eliminated exemptions for wind generators from the requirement to provide reactive power. Reactive power is needed to start and operate motors, transformers, and relays. Transmission system operators need generators to either supply or consume reactive power to maintain system voltage. Under the Large Generator Interconnection Agreement (see

\footnotetext{
${ }^{10}$ FERC established an employment threshold for entities to be affected by Order 819 . To receive market-based rates for PFR service, conventional generators must have at least 750 employees, while renewable energy generators including solar, wind, and biomass generators must have at least 250 employees.
} 
section 3.6) large generators are required to provide 0.95 leading and 0.95 lagging reactive power to the transmission network. Order 827 revised the Large Generator Interconnection Agreement to include reactive power requirements for wind generators, since technology improvements in recent years had made the equipment needed for wind generators to provide reactive power both commercially available and less costly (FERC 2016b).

\subsection{Summary of Federal Interconnection Policies}

Table 5. Interconnection Topics Addressed by Federal Transmission Policies

\begin{tabular}{|c|c|c|c|c|}
\hline Laws and Regulations & $\begin{array}{l}\text { Transmission } \\
\text { Access }\end{array}$ & $\begin{array}{l}\text { Market Rules } \\
\text { and Tariffs }\end{array}$ & $\begin{array}{l}\text { Balancing } \\
\text { Areas }\end{array}$ & $\begin{array}{l}\text { Interconnection } \\
\text { Procedures }\end{array}$ \\
\hline PURPA & $\checkmark$ & $\checkmark$ & & \\
\hline Energy Policy Act of 1992 & $\checkmark$ & $\checkmark$ & & \\
\hline FERC Order 888 & $\checkmark$ & $\checkmark$ & $\checkmark$ & \\
\hline FERC Order 889 & $\checkmark$ & & & \\
\hline FERC Order 2000 & & & $\checkmark$ & \\
\hline FERC Orders $2003 \& 661$ & & & & $\checkmark$ \\
\hline FERC Orders 2006 \& 792 & & & & $\checkmark$ \\
\hline Energy Policy Act of 2005 & $\checkmark$ & $\checkmark$ & & \\
\hline FERC Order 890 & $\checkmark$ & $\checkmark$ & $\checkmark$ & \\
\hline FERC Order 1000 & & $\checkmark$ & $\checkmark$ & \\
\hline FERC Order 764 & $\checkmark$ & & & \\
\hline FERC Order 784 & & $\checkmark$ & & \\
\hline FERC Orders $819 \& 827$ & & $\checkmark$ & & $\checkmark$ \\
\hline
\end{tabular}




\section{Subnational Policies on Renewable Energy Grid Interconnections}

This section reviews subnational procedures and regulations related to renewable energy interconnections in the United States. It is not uncommon for state governments to enact policies that go beyond what is required by federal legislation.

To understand the potential impacts of subnational interconnection policies in the United States, it is important to distinguish between state and federal jurisdiction for generator interconnections. Generators that interconnect with an electric facility exclusively making retail sales do not fall under FERC jurisdiction and are subject to state interconnection rules. Some facilities are considered "duel use" because they are subject to both state and federal jurisdiction (Michaud 2007). For example, while FERC established an 80 MW upper limit for "small powerproducing facilities," Minnesota enacted a law to establish state-wide uniform contracts for qualifying facility interconnections with no maximum capacity limits (Michaud 2007).

\subsection{Transmission and Integration Planning: Regional and State Initiatives}

In addition to the state and regional authorities outlined in Table 2, beginning in 2004, several states created transmission infrastructure authorities to coordinate system planning and expansion (Porter and Fink 2008). In general, these authorities emerged in states that have high quality renewable resources. ${ }^{11}$ Giving sufficient capabilities to the authorities has proven to be important to their ultimate success. Colorado's Clean Energy Development Authority, for example, has had little impact on transmission development within the state, partially due to lack of allocated budget for staffing and weak financing capabilities. The Kansas Development Finance Authority, on the other hand, was given more flexibility to issue taxable and tax-exempt bonds and has proven more impactful on transmission development to promote renewable energy integration within the state.

Integrated planning efforts are also underway in a number of other venues. For example, the Western Governors' Association (WGA), a non-partisan association that represents the Governors of 19 Western states and 3 U.S Territories, is coordinating a multi-phase study named the Western Renewable Energy Zones (WREZ) project to identify areas with high quality renewable resources, determine which of the zones are of greatest interest to developers, and plan for a transmission network that will bring those resources to the load centers (WGA 2015).

In 2009, WGA published the Phase 1 report, which provides a view of where the richest, most commercially viable renewable resources are within the Western Interconnection. Subsequent phases of the WREZ project include:

\footnotetext{
${ }^{11}$ For instance, the New Mexico Renewable Energy Transmission Authority (RETA) was the first infrastructure authority specifically created to promote RE development. A minimum of $30 \%$ of the energy handled by any transmission project that RETA undertakes must be generated from renewable resources. RETA is considered an economic development tool to bring New Mexico's significant solar, biomass, and wind energy potential to markets. The state has an RPS; however, renewable energy demand within the state is relatively small. A focus of the RETA is to develop export potential to larger neighboring renewable energy markets, such as those in Arizona and California.
} 
- Analyzing transmission requirements under a broad range of alternative energy futures and developing long-term, interconnection-wide transmission expansion plans. This is done by the Western Electricity Coordinating Council (WECC), one of the eight NERC regional entities, every two years.

- Developing state-level wildlife decision support systems that can be used to help assess the viability of new energy generation and transmission in certain areas.

- Examining the regional impacts of new energy generation on water use, including a look at the potential impacts of long-term drought on energy production.

Most RTOs also undertake ongoing integrated regional planning initiatives. The Midcontinent Independent System Operator (MISO) Transmission Expansion Plan, for example, is an annual study that evaluates and proposes transmission projects to maintain grid reliability and ensure cost-effectiveness of energy. Southwest Power Pool's Integrated Transmission Planning process occurs every three years and includes near-term, 10-year, and 20-year assessments for transmission system planning and cost allocation.

\subsection{Interconnection Standards}

Until the early 2000s, individual utilities determined interconnection procedures on a case-bycase basis. Utilities typically applied the federal interconnection standards that were outlined in PURPA in 1978, which were not designed to accommodate DG such as rooftop solar PV (Coddington et al. 2012). In 2000, California became the first state to enact a uniform interconnection standard for DG interconnections. California's Rule 21 made it easier and faster for utilities to make decisions about DG interconnection applications (see Text Box 5). Since that time, many states have adopted interconnection standards that are designed to remove unnecessary barriers to entry for DG and small generators. As of 2012, 44 states as well as the District of Columbia and Puerto Rico have interconnection standards or guidelines in place (Coddington et al. 2012). Despite uniform state-wide standards, utilities retain at least some discretion. For generators that do not fall under fast-track interconnection procedures, utilities determine which studies are necessary, the depth of their review, and the interconnection timeline (Keyes 2008).

While FERC has authority over all large generator interconnections (i.e., generators with $20 \mathrm{MW}$ or more generating capacity), RTOs and ISOs have greater flexibility for complying with FERC's interconnection standards. RTOs and ISOs use FERC Orders 2003 and 792 as a baseline to design their own interconnection procedures with unique system-specific features, while FERC retains oversight and approval rights for all system operators except for ERCOT (see Text Box 1). In general, RTOs and ISOs follow FERC guidelines regarding wind integration procedures. They follow FERC Orders 661 and 661-A for their OATTs and technical criteria for wind plants, including low-voltage ride-through requirements (Porter et al. 2009). 


\section{Text Box 4. California's Rule 21}

California's Rule 21, first adopted in 2000, created state-wide standards for interconnection, and operating and metering requirements for DG interconnections. The rule required all DG systems to apply to the California Independent System Operator (CAISO), the entity responsible for open-access transmission service, for interconnection approval. It also required utilities to interconnect DG systems to the distribution or transmission system in a non-discriminatory manner. Therefore, all DG systems interconnected under CAISO's jurisdiction became subject to CAISO's transmission and distribution tariffs. This helped to standardize and streamline the interconnection process for small (e.g., commercial and residential roof-top) PV systems. In the intervening years since its inception, California's Rule 21 was amended and expanded to include additional interconnection requirements for DG systems such as smart inverter functions, and to synchronize the rule with the recommended requirements set forth in the Institute of Electrical and Electronic Engineers (IEEE) 1547-2003 Standards for Interconnecting Distributed Resources with Electric Power Systems. See http://www.cpuc.ca.gov/General.aspx?id=3962 for more information on Rule 21.

\subsection{Feed-in Tariffs and Net Metering}

A feed-in tariff (FIT) guarantees payments to renewable energy generators for all the electricity they supply to the grid under a fixed-term contract, typically for a period of 5-20 years. The FIT rate is typically higher than the retail rate of electricity, and rates paid to renewable energy generators under FITs can vary based on the desired level of promotion for a specific technology. Experience with FITs is limited in the United States compared with some European markets such as Germany, where FITs are widely implemented. Currently, six states (California, Hawaii, Maine, Oregon, Vermont, and Washington) mandate FITs or similar programs that are implemented by local utilities in those states. In other states, some utilities have voluntarily provided FIT incentives. For example, Dominion Virginia Power's voluntary FIT provides residential and commercial PV owners with a 15 cent/kWh power purchase contract for all electricity supplied to the grid for 5 years (Dominion Virginia Power 2016).

Net metering policies are closely related to FITs in that they provide a production-based incentive to commercial and residential distributed renewable energy generators. Net metering grants per-kWh credits toward end-use customers' monthly electric bills based on the amount of electricity the customer-cited renewable energy generator supplies to the grid. Figure 5 depicts the forty-one states, the District of Columbia, and four U.S. territories that have adopted some form of state-wide net metering policy. 


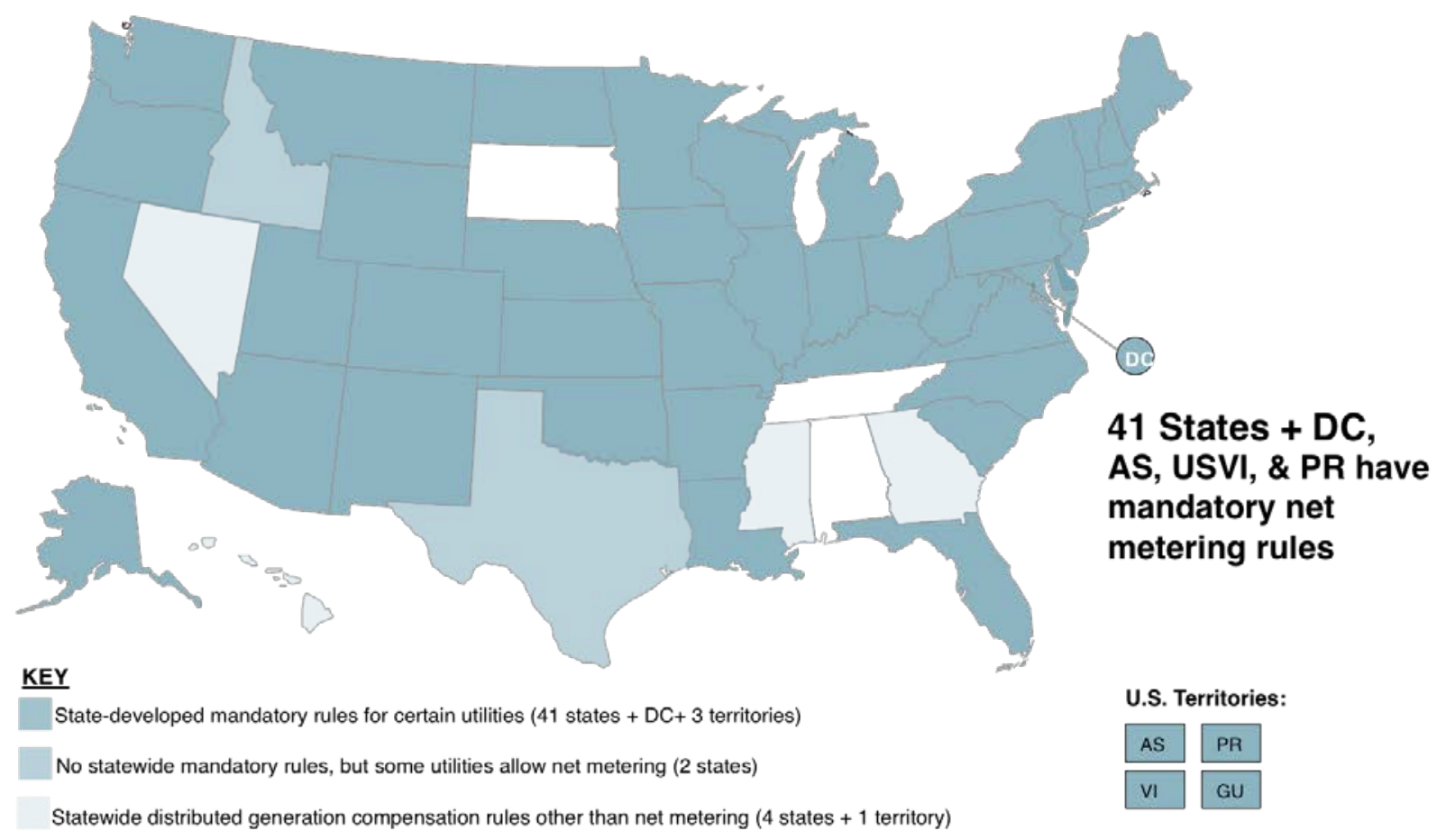

Figure 5. States with net metering policies (as of February 2016)

Source: DSIRE (2016)

U.S. Territories with net metering rules include American Samoa, U.S. Virgin Islands, and Puerto Rico 


\section{Conclusion}

Grid interconnection policies serve as an important backdrop to broader reforms and market factors influencing the integration of renewable energy (renewable energy) on the electric grid. This report reviews current interconnection policies for renewable energy generators and provides a brief history of the regulatory landscape for interconnection policies in the United States. Where appropriate, integration policies and their implications for renewable energy are discussed within the broader context of wholesale power market reform.

The purpose of this report is to clearly outline the stakeholders and institutional framework under which interconnection policies are established and implemented in the United States, and to enable power sector practitioners to navigate renewable energy interconnection policies in the United States. Ultimately, this report aims to serve as a reference and guidance document for stakeholders involved in designing and implementing power system practices. The laws and regulations discussed in this report can serve as illustrative examples for regulators and power system practitioners seeking to update interconnection policies and procedures to enable the growth of renewable energy, including variable renewables such as wind and solar, in the electric power system. 


\section{References}

Abel, Amy. 1998. Electricity Restructuring Background: The Public Utility Regulatory Policies Act of 1978 and the Energy Policy Act of 1992. Washington D.C.: UNT Digital Library. Accessed June 2016. http://digital.library.unt.edu/ark:/67531/metacrs642/.

Anderson, Glen. 2016. Integrating Renewable Energy. Washington, D.C.: National Conference of State Legislatures. Accessed June 2016. http://www.ncsl.org/Portals/1/Documents/energy/Integrating_Renewable \%20Energy_616.pdf.

Beiter, Philipp. 2015. 2014 Renewable Energy Data Book. DOE/GO-102015-4724. Golden, CO: National Renewable Energy Laboratory. Accessed June 2016. http:/www.nrel.gov/docs/fy16osti/64720.pdf.

Bloom, David, J. Paul Forrester, and Nadav Klugman. 2010. "Current Conflicts in U.S. Electric Transmission Planning, Cost Allocation and Renewable Energy Policies: More Heat than Light?" The Electricity Journal 23(10):8-17.

Burns, Robert E., and Mark Eifert. 1993. A White Paper on the Energy Policy Act of 1992: An Overview for State Commissions of New PURPA Statutory Standards. NRRI93-6. Columbus, OH: National Regulatory Research Institute. Accessed June 2016. http://www.ipu.msu.edu/library/pdfs/nrri/Burns-Eifert-White-Paper-PURPA-Standards93-6-Apr-93.pdf.

California ISO. 2015. "Glossary of key terms and acronyms.” Last updated November 13. http://www.caiso.com/Pages/glossary.aspx.

Casazza, Jack, and Frank Delea. 2004. "History of Electric Power Industry." In Understanding Electric Power Systems, 1-11. Hoboken, NJ: Wiley.Cochran, Jaquelin, Lori Bird, Jenny Heeter, and Douglas J. Arent. 2012. Integrating Variable Renewable Energy in Electric Power Markets: Best Practices from International Experiences. NREL/TP-6A00-53730. Golden, CO: National Renewable Energy Laboratory. Accessed June 2016. http://www.nrel.gov/docs/fy12osti/53732.pdf.

Coddington, Michael, Kevin Fox, Sky Stanfield, Laurel Varnado, Thad Culley, and Michael Sheehan. 2012. Updating Small Generator Interconnection Procedures for New Market Conditions. NREL/TP-5500-56790. Golden, CO: National Renewable Energy Laboratory. http://www.nrel.gov/docs/fy13osti/56790.pdf.

Davis, Tracy C. 2013. “FERC's Regional Transmission Planning Policy Takes Shape.” The Electricity Journal 26(7):22-32.

Dismukes, David E., and Andrew N. Kleit. 199). "Cogeneration and Electric Power Industry Restructuring." Resource and Energy Economics 21(2):153-66. 
Dominion Virginia Power. 2016. "Solar Power Purchase Program.” Accessed June. https://www.dom.com/residential/dominion-virginia-power/ways-to-save/renewableenergy-programs/solar-purchase-program.

DSIRE (Database of State Incentives for Renewables \& Efficiency). 2016. "Net Metering." Updated February. http://ncsolarcen-prod.s3.amazonaws.com/wpcontent/uploads/2016/02/Net_Metering_022016.pdf.

EIA (Energy Information Administration). 2015. "Wind generates more than $10 \%$ of Texas electricity in 2014." Today in Energy, February 19. Accessed June 2016. http://www.eia.gov/todayinenergy/detail.cfm?id=20051.

“FERC Order 888: No Real Surprises, Full Speed Ahead." 1996. The Electricity Journal 9(5):11, 84.

FERC (Federal Energy Regulatory Commission). 2005. “Order No. 661: Interconnection for Wind Energy.” 111 FERC \ 61,353. Issued June 2. Accessed June 2016. http://elibrary.ferc.gov/idmws/common/opennat.asp?fileID=10594521.

- 2006. "Fact Sheet - Energy Policy Act of 2005." Washington, D.C.: Federal Energy Regulatory Commission. Accessed June 2016. https://www.ferc.gov/legal/fed-sta/epactfact-sheet.pdf.

. 2013a. "Order No. 792: Small Generator Interconnection Agreements and Procedures." 145 FERC 161,159 . Issued November 22. Accessed June 2016. https://www.ferc.gov/whats-new/comm-meet/2013/112113/E-1.pdf.

. 2013b." Order No. 784: Third-Party Provision of Ancillary Services; Accounting and Financial Reporting for New Electric Storage Technologies.” 144 FERC 1 61,056. Issued July 18. Accessed June 2016. https://www.ferc.gov/whats-new/commmeet/2013/071813/E-22.pdf.

- 2013c. "Glossary." Last updated August 20. http://www.ferc.gov/resources/glossary.asp.

—. 2014. "Final Rule Transmission Planning and Cost Allocation by Transmission Owning and Operating Public Utilities." Presentation. Washington, D.C.: Federal Energy Regulatory Commission. Accessed June 2016. http://www.ferc.gov/media/newsreleases/2011/2011-3/07-21-11-E-6-presentation.pdf.

- 2015a. "History of OATT Reform." Accessed August 24. https://www.ferc.gov/industries/electric/indus-act/oatt-reform/history.asp.

- 2015b. "Landmark Orders - Order 2003." Accessed August 24. http://www.ferc.gov/legal/maj-ord-reg/land-docs/order2003.asp. 
- 2015c. "Third-Party Provision of Primary Frequency Response Service." 153 FERC 9 61,220. Issued November 20. Accessed August 2016. https://www.ferc.gov/whatsnew/comm-meet/2015/111915/E-1.pdf

2016a. "Essential Reliability Services and the Evolving Bulk-Power System-Primary Frequency Response.” 154 FERC $\$$ 61,117. Issued February 18. Accessed August 2016. https://www.ferc.gov/whats-new/comm-meet/2016/021816/E-2.pdf

_ 2016b. "Reactive Power Requirements for Non-Synchronous Generation." 155 FERC $\uparrow$ 61,277. Issued June 16. Accessed August 2016. https://www.ferc.gov/whats-new/commmeet/2016/021816/E-2.pdf

Fine, Howard. 2012. "Regulators Approve Edison Coal Plant Sale.” Los Angeles Business Journal, March 23. http://labusinessjournal.com/news/2012/mar/23/edison-sells-coalplant-294-million/.

Fink, Sari, Kevin Porter, and Jennifer Rogers. 2010. The Relevance of Generation Interconnection Procedures to Feed-in Tariffs in the United States. NREL/SR-6A2048987. Prepared by Exeter Associates, Columbia, Maryland. Golden, CO: National Renewable Energy Laboratory. Accessed June 2016. http://www.nrel.gov/docs/fy11osti/48987.pdf.

Gipe, Paul. 1991. "Wind energy comes of age California and Denmark." Energy Policy 19(8):756-767.

Greenfield, Lawrence R. 2010. An Overview of the Federal Energy Regulatory Commission and Federal Regulation of Electric Utilities in the United States. Washington, D.C.: Federal Energy Regulatory Commission. Accessed June 2016. http://www.ferc.gov/about/fercdoes/ferc101.pdf.

Hirsh, Richard F. 1999. "PURPA: The Spur to Competition and Utility Restructuring." The Electricity Journal 12(7):60-72.

Hirst, E. 2001. Real-time balancing operations and markets: key to competitive wholesale electricity markets. Oak Ridge, TN: Oak Ridge National Laboratory. http://wp.ornl.gov/sci/ees/etsd/pes/pubs/RTMReport.pdf.

Hurlbut, David J. 2010. "Multistate Decision Making for Renewable Energy and Transmission: An Overview." University of Colorado Law Review 81(3):677-703. http://lawreview.colorado.edu/wp-content/uploads/2013/11/8.-Hurlbut-Final_s.pdf.

Hurlbut, David J., Ilya Chernyakhovskiy, and Jaquelin Cochran. 2016. "Renewable Energy Zones: Delivering Clean Power to Meet Demand." Greening the Grid Fact Sheet. Accessed August 2016. http://greeningthegrid.org/resources/factsheets/renewableenergy-zones

IEPA (Independent Energy Producers Association). 2015. “Avoided Cost.” Accessed August 24. http://www.iepa.com/avoid.asp. 
Joskow, Paul L. 1997. "Restructuring, competition and regulatory reform in the US electricity sector." The Journal of Economic Perspectives 1997:119-138.

Keyes, Jason B. 2008. The Development of Interconnection Standards in Six States in 20072008. Interstate Renewable Energy Council. Paper presented at the Solar 2008 Conference, San Diego, California, May. Accessed June 2016. http://www.osti.gov/scitech/servlets/purl/1023803.

Lantz, Eric, Daniel Steinberg, Michael Mendelsohn, Owen Zinaman, Ted James, Gian Porro, Maureen Hand, Trieu Mai, Jeffrey Logan, Jenny Heeter, and Lori Bird. 2014. Implications of a PTC Extension on U.S. Wind Deployment. NREL/TP-6A20-61663. Golden, CO: National Renewable Energy Laboratory. Accessed June 2016. http://www.nrel.gov/docs/fy14osti/61663.pdf.

Malmedal, Keith, Benjamin Kroposki, and Pankaj Sen. 2007. "Energy Policy Act of 2005." IEEE Industry Applications Magazine 13(1):14-20.

Merrill, Hyde M. 2000. "Regional transmission organizations: FERC Order 2000.” IEEE Power Engineering Review 20(7):3-5.

Michaud, Mike. 2007. Untangling FERC \& State Jurisdiction Interconnection Issues and Opportunities for Dispersed Generation. Prepared for North American Water Office and C-BED Initiative. http://www.c-bed.org/pdf/Jurisdiction_White_Paper_2007-11-16.pdf.

Miller, Mackay, and Sadie Cox. 2014. Overview of Variable Renewable Energy Regulatory Issues: A Clean Energy Regulators Initiative Report. NREL/TP-6A20-61350. Golden, CO: National Renewable Energy Laboratory. Accessed June 2016. http://www.nrel.gov/docs/fy14osti/61350.pdf.

Milligan, Michael, Bethany Frew, Brendan Kirby, ..., and Bruce Tsuchida. 2015. "Alternatives No More: Wind and Solar Power Are Mainstays of a Clean, Reliable, Affordable Grid," in IEEE Power and Energy Magazine, vol. 13, no. 6, pp. 78-87, Nov.-Dec. 2015.

NERC (North American Electric Reliability Corporation). 2014. Project 2010-17: Definition of the Bulk Electric System (Phase 2). Atlanta: North American Electric Reliability Corporation. Accessed June 2016. http://www.nerc.com/pa/RAPA/BES\%20DL/BES\%20Definition\%20Approved\%20by\%2 $\underline{\text { 0FERC } \% 203-20-14 . p d f}$

- 2015. Rules of Procedure of the North American Electric Reliability Corporation. Atlanta: North American Electric Reliability Corporation. Accessed June 2016. http://www.nerc.com/FilingsOrders/us/RuleOfProcedureDL/NERC ROP Effective 201 50319.pdf.

2016. "Ensuring the Reliability of the Bulk Power System.” Fact sheet. Atlanta: North American Electric Reliability Corporation. Accessed June 2016. http://www.nerc.com/news/Documents/NERC\%20One\%20Pager\%2003JUNE16.pdf. 
Norton, Floyd L., and Michael Keegan. 2011. "Practical Consequences Arising from FERC's Secondary Electric Transmission Market." The Electricity Journal 24(3):34-44.

Parsons, B., and K. Porter. 2002. Regional Transmission Organizations and Wind Energy: A Happy Marriage or Divorce Proceedings? NREL/CP-500-32467. Paper presented and the American Wind Energy Association (AWEA) WINDPOWER 2002 Conference, Portland, Oregon, June 2-4. Accessed June 2016. http://www.nrel.gov/docs/fy02osti/32467.pdf.

Porter, K. and S. Fink. 2008. State Transmission Infrastructure Authorities: The Story so Far. NREL/SR-500-43146. Prepared by Exeter Associated, Columbia, Maryland. Golden, CO: National Renewable Energy Laboratory. Accessed June 2016. http://www.nrel.gov/docs/fy08osti/43146.pdf.

Porter, K., S. Fink, C. Mudd, and J. DeCesaro. 2009. Generation Interconnection Policies and Wind Power: A Discussion of Issues, Problems, and Potential Solutions. NREL/SR-55044508. Prepared by Exeter Associates, Columbia, Maryland. Golden, CO: National Renewable Energy Laboratory. Accessed June 2016. http://www.nrel.gov/docs/fy09osti/44508.pdf.

Porter, Kevin. 1996. Open Access Transmission and Renewable Energy Technologies. NREL/SP-460-21427. Golden, CO: National Renewable Energy Laboratory. http://www.nrel.gov/docs/legosti/old/21427.pdf.

Pub.L. 95-617 (Public Law 95-617). 1978. “An Act to suspend until the close of June 30, 1980, the duty on certain doxorubicin hydrochloride antibiotics." Public Utility Regulatory Policies Act of 1978.

Quinn, J. Arnold. 2015. "Introduction to Electric Power Regulation and Electricity Markets." Webinar, July 9. http://www.epa.gov/sites/production/files/201507/documents/20150709webinar.pdf.

Snarr, W. Steven. 2009. "The Commerce Clause and Transmission Infrastructure Development: An Answer to Jurisdictional Issues Clouded by Protectionism." The Electricity Journal 22(5):8-18. http://dx.doi.org/10.1016/j.tej.2009.04.005.

Trachsel, Herman Henry. 1947. Public Utility Regulation. Chicago: R.D. Irwin.

Udren, Eric, and Charles W. Rogers. 2010. "The new NERC protection system maintenance standard." Paper presented at the IEEE 63rd Annual Conference for Protective Relay Engineers, College Station, Texas, March 29-April 1.

Watkiss, Jeffrey D., and Douglas W. Smith. 1993. "Energy Policy Act of 1992-A Watershed for Competition in the Wholesale Power Market." The Yale Journal on Regulation 10:447.

WGA (Western Governors' Association). 2015. "Western Renewable Energy Zones." Accessed June. http://www.westgov.org/rtep/219. 
Wiser, Ryan, Mark Bolinger, and Galen Barbose. 2007. "Using the federal production tax credit to build a durable market for wind power in the United States." The Electricity Journal 20(9):77-88.

Woodfin, Dan. 2008. “CREZ Transmission Optimization Study Summary." Presentation to the ERCOT Board of Directors, April 15. http://www.ercot.com/meetings/board/keydocs/2008/B0415/Item_6_CREZ_Transmission_Report to PUC__Woodfin_Bojorquez.pdf.

Zhang, Y., Gevorgian, V., Ela, E., Singhvi, V., \& Pourbeik, P. (2013). Role of wind power in primary frequency response of an interconnection. National Renewable Energy Laboratory (NREL), Golden, CO, USA 